\title{
Perception of Emotional Intelligence (EI) of the Private University Faculty Members of Bangladesh
}

\author{
Taslima Khatun Mahajabin Tabassum Sujana* Mohammad Abul Khayer \\ Faculty of Business Administration, Feni University, Trunk Road Feni 3900, Bangladesh
}

\begin{abstract}
The human world is changing and becoming more complex day by day. So work pressure, fear, anxiety, stress, depression is a common cognitive issues that every employee faces in the workplace which affect their productivity, performance, morale and so on. This paper attempts to find out the perception level of private university faculties in Bangladesh upon emotional intelligence. The scope of the study has been done about private universities faculties, where sample size is $(\mathrm{N}=250)$. The collected data has-been analyzed using mean, standard deviation and regression analysis. Overall this research contributes a meaningful implication about emotional intelligence and how private university faculties perceive them.
\end{abstract}

Keywords: Emotional Intelligence, Self-awareness, Self-management, Self-Motivation, Social Skill and Private University.

DOI: $10.7176 / \mathrm{EJBM} / 11-18-21$

Publication date:June $30^{\text {th }} 2019$

\section{Introduction}

Now a days, the concept of Emotional Intelligence (EI) has gained popularity in the public and private sector employees because it affects the workplace performance. The perception varies from person to person. EI is an indispensible factor for determining employee's creative abilities and how these abilities shape their behavior. According to Khokhar and Kush (2009), "Employees who are skilled at valuing their own emotions are better in communicating their needs and they would be able to be more concern towards their own feelings in order for them to accomplish their goals resulting better performance". A General assumption is that people with strong EI have greater control upon himself (George, 2000; Day \& Carroll, 2004).

Emotional Intelligence is an ability to be self-aware of emotions and to express oneself correctly. When a person is aware of his emotions, he goes on the next level-emotional assimilation, which is to differentiate between the different emotions he or she is undergoing and also mark out those emotions that affect his or her thought process. This ability leads him to the emotional understanding; an ability to understand difficult emotions and also to identify the transfer from one emotion to another. By then he or she becomes learned in dealing with his or her emotions and thus he or she is able to conduct his emotions by connecting to or disconnecting from any emotion at any given condition. This gives him complete control over his inspiration and thus able to think, explore and act rationally in any situation. (Gayathri \& Meenakshi, 2013).

\subsection{Rationale of the Study:}

Faculties who have control over their emotions more carefully rather than reacting to the situation, they have more manageable capabilities to their self and social awareness along with their self-motivation capabilities. These types of people are more successful than the others. In this study, the data has been obtained from different private university faculties to know their perception about self-emotional balance.

\subsection{Objectives of the Study:}

- To examine the dimensions of Emotional Intelligence.

- To find out the perception of Emotional Intelligence of the private university faculties of Bangladesh.

- To empirically test the emotionally balanced employees.

\section{Research Methodology:}

The research is descriptive in nature based on a survey. Sample Unit for this research study consists of university teachers of private sector who has been taught in different departments and progress in respective fields. Convenient sampling technique has been adopted 834 questionnaire (Appendix A) were floated to the faculty members of private universities in Bangladesh. Within 834 questionnaires 250 were received.

Data collection method has been used in this research in order to relate the literatures. Primary data has been collected and attempted to assess the Perception of EI. The survey has been administered by using a questionnaire (Appendix) consisting close questions. Four dimension has been used as prime parameters in the form of independent variables to find dependent variable i,e. perception of EI.SPSS 16.00 has been used to analyze the findings.

The primary data was collected by floating $\mathbf{8 3 4}$ questionnaires among different university teachers out of $\mathbf{2 5 0}$ 
were raised.

\section{Literature Review:}

Emotional intelligence is a blend of capabilities that incorporates the possibility to discern feelings in the self and in other individuals, utilize feelings to improve execution, comprehend feelings and enthusiastic information and direct feelings in the self and in other individuals (Mayer and Salovey, 1997). Ekmen (1992) states that emotions are part of what makes us all human and their influence cannot be denied. Moreover, these effect issues related with the workplace between individuals and groups (Fisher\& Ashkanasy, 2000). High EI in employees lead to greater performance whereas a lack of EI will cause a decrease in performance (Ali, 2013). Employees who show greater EI better than those who mask and repress their feelings (Grandey, 2003; Grandey et al, 2005 as cited in Tahir, Saba \& Rabbia, 2013).

Bob Wall (2008) as cited in (Ali, 2003), states that in addition to their technical skill, employees should focus on improving their emotional intelligence. Arguably the most essential outcome of EI is that it helps workers better understand and respond to emotion in the workplace (Salvery \& Mayer, 1990).

Organizations are fields where individuals are organized to work. In such places, emotions such as excitement, anger and fear are inevitable. Employees who are emotionally intelligent are very proficient and operative in their interaction with the work environment and with their co-workers. So far various studies have been conducted on emotional intelligence of teachers (Akomolafe, 2011). The role of emotions and emotional intelligence as a means to improve balanced employees in education (Arnold, 2005 , Jennings and Greenberg , 2009 ; Rohana ,Kamaruzaman and Zanariah , 2009 ; Sotton , 2004 ; Najmuddin , Noriah and Mohamad , 2011). Researchers had theorized that emotional intelligence influences job performance of employees (Carmeli \& Josman, 2006 ; Shih \& Susanto , 2010).

Interestingly, Corcoran and Tormey (2012) found that emotional intelligence contributes positively towards the teaching role. Specifically, researcher asserts that employees emotional intelligence can predict work related outcomes such as emotionally balanced employees. (Bachman, et al.) Many research works have identified emotional intelligence as a critical factor in the behavior and performance of individual workers in organization (Ciarrochi, Chan, \& Caputi 2000; Ciarrochi, Deane \& Anderson 2000, Cherniss, 2001; Goleman, 1996; Mayer \& Salovely, 1990).Teachers who are able to manipulate their emotions seem to be more understanding and caring to the needs of students and better in monitoring their negative emotions to facilitate a positive classroom environment ( Kremenitzer \& Miller, 2008).

Emotional Intelligence is influenced by self-awareness, self-management, social skill and self-motivation, So in this paper Emotional Intelligence has been taken as a dependent variable. Moreover, the paper is presented emotionally balanced employees. The variables which has been used in the questionnaire, its implication are too represents balanced employees characteristics. As, an emotionally balanced employees are considered as an asset in an organization whereas his or her productivity, performance, job satisfaction, job commitment, job loyalty increase; on the other hand turnover, absenteeism decrease in a great extent. That is why an organization badly needed strong emotionally balanced employee. This paper just identifies strong Emotional intelligence faculties among the private universities or how the faculties perceive emotional intelligence in their workplace.

\subsection{Research Questions}

Self-awareness: Does self-awareness have any impact or influence on Emotional Intelligence?

Self-management: Does self-management have positive connection with the private university faculties?

Social skill: Does social skill help to increase maintain relationship with others?

Self-Motivation: Does self-motivation increase the skills of employee?

\section{Dimensions and Hypothesis of Emotional Intelligence \\ 4.1 Self-Awareness}

Self-awareness is the most crucial factor associated with workplace emotional intelligence. Grayson (2013) defined self-awareness as the ability to recognize one's feelings, to differentiate between to know what one is feeling and why and to know what caused the feelings. Goleman (1998) defined emotional self-awareness as a way to identifying a person's emotions and how it could effect. Yeung (2009) stated that the first step of becoming an emotionally intelligent is to become as self -aware as possible. He also argues that if emotional intelligence were a journey, then, self-awareness would be the skill of map reading.

In the questionnaire, with this dimension people know about private universities faculties strength and weaknesses which is affect their performance, success , making rational decision and overall their inner potentiality which leads them to conduct their job properly. So it is expected that the hypothesis is-

H1: Self-awareness has significant impact or influence on Emotional Intelligence. 


\subsection{Self-Management}

Self-management refers to one's ability to control and mitigate one's emotional response to others. This includes the choice of appropriate emotional reaction and the intensity of that reaction. This is associated with the behavior and emotional cues of others (Georgiana, 2014).

The second dimension is self-regulation or self-management which leads those people who can control their emotions, manage their feelings, and maintain transparency and ethical standard -these types of people also love to take challenging goals and tasks. So the hypothesis is-

\section{H2: Self-management has positive impact on inter personal skills.}

\subsection{Social Skill}

Social skills refer to a person's talent in managing relationship with others and building systems also called people skills. The set of social skills includes respect for others, mutual regard, commitment, openness, tolerance, empathy, negotiation, communication etc. (Schuetz, 2011). It involves the ability of meeting each other's needs relating to each other's over time and exchanging information about one's feelings, thoughts and ideas. Social skills are effective in leading change, persuading others, building and leading teams (Goleman 1998). Social interaction also results in many advantages. It gives confidence and social acceptance. It can help managers in many ways. It can help do many things which cannot be completed alone; Such as, getting support from a team or completing a project (Pettry, 2006).

Social skill dimension represents maintaining close relationship with supervisors, colleagues, and peer group, subordinate, seeking mutual cooperation and resolve employee conflict .So the estimated hypothesis is-

H3: Social skill helps to increase managing relationship with others.

\subsection{Self- motivation}

Self - motivation refers to the skill of managing one's time properly. People who are motivated tend to be happier and feel more self -assured. In simple terms motivation is what propels to achieve their goals (Peter \& John). It also includes - maintain stress and anxious, motivate oneself etc. which increase a person's productivity. So the expected hypothesis is-

\section{H4: Self-motivation overcomes the personal difficulties.}

\section{Conceptual model and Hypothesis}

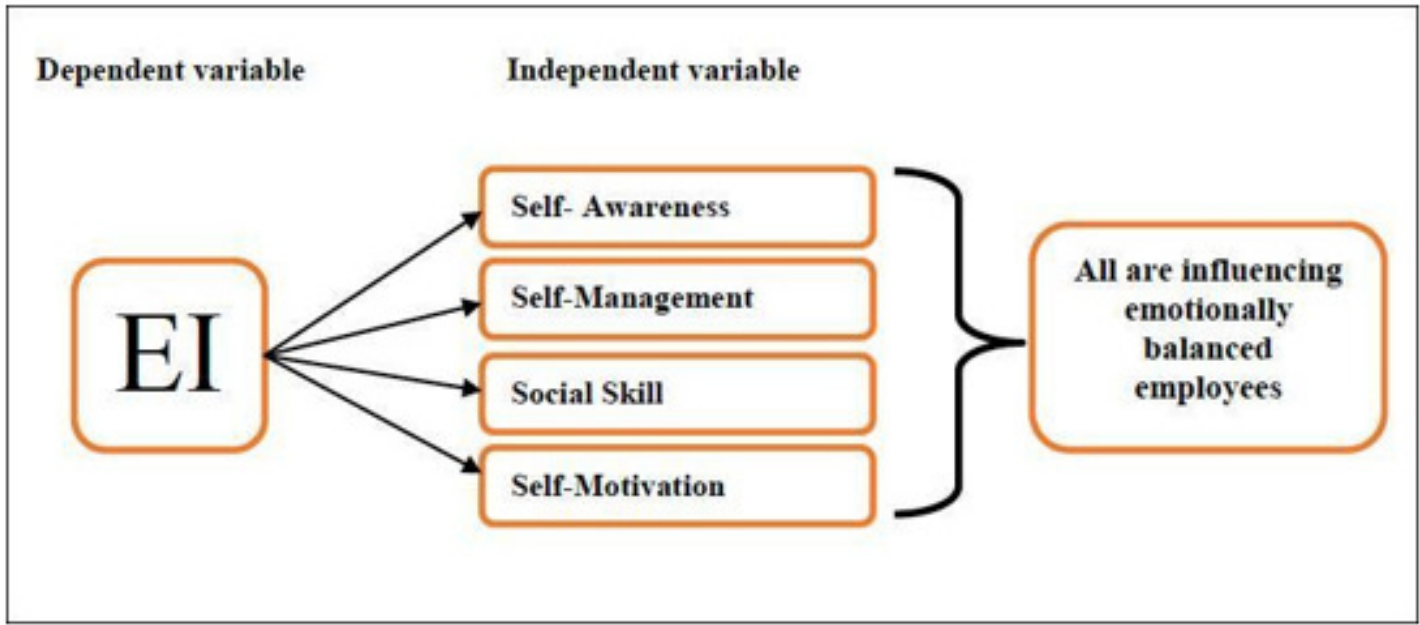

Figure 1: Conceptual EI Model 


\subsection{Four aspects of EI}

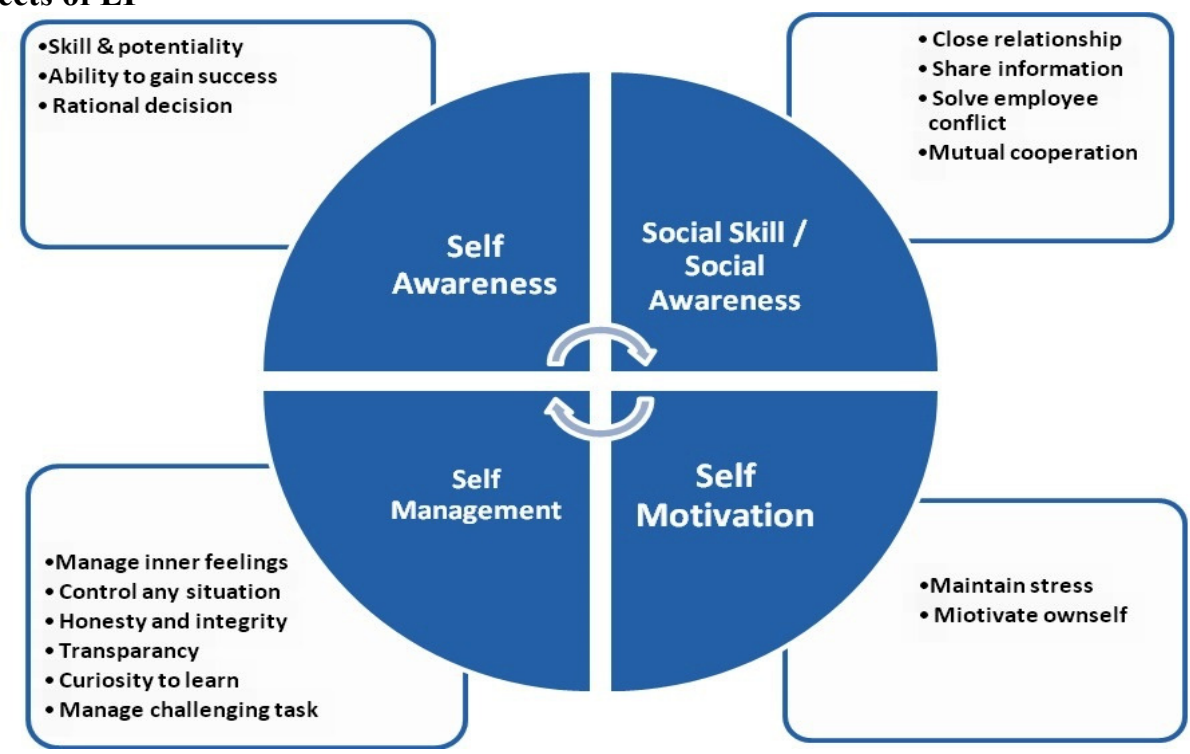

Figure 2: Four aspects of EI

\section{Analysis and Findings}

Table-1 Demographic profile of respondents

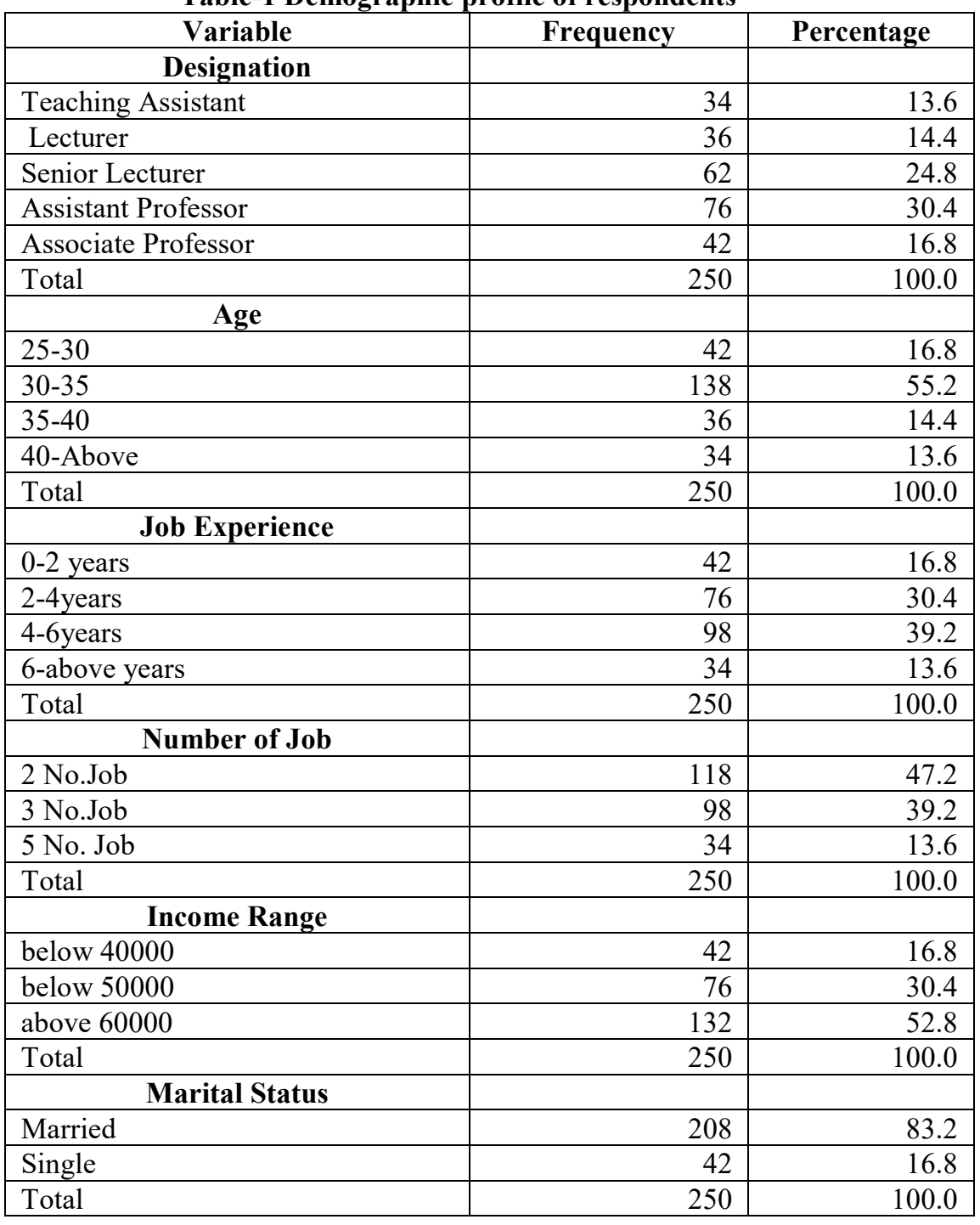


Table1: represents the descriptive investigation on the demographic profile of faculties. It appears that faculties are mostly in the age categories 30-35 years old (55.2\%). The second highest of respondents are in the age categories is 25-30 years that is (16.8\%). First categories age belongs to the Senior Lecturer, Assistant Professor and most of the cases Associate professor. In case of designation these variable in the table shows that Assistant professor and senior Lecturer faculties are more responsive. On the other hand we did not get any response from professor level faculties. In above table, it presents that the majority percent respondents are in 4-6 years job experience $(39.2 \%)$ whereas $2-4$ years faculties job experience is $(30.4 \%)$. With regards to the income level the majority respondents are above 60000 that is $(52.8 \%)$ which this paper represents them Assistant professor and Associate professor faculties. Finally this table also shows that most of the respondents are married which gives a positive message that private universities faculties are more stable in their psychological issues.

Table-2 Descriptive Statistics Analysis

\begin{tabular}{|c|c|c|c|}
\hline \multicolumn{4}{|c|}{ Descriptive Statistics } \\
\hline Factors of Dimensions & $\mathbf{N}$ & Mean & $\begin{array}{c}\text { Std. } \\
\text { Deviation }\end{array}$ \\
\hline \multicolumn{4}{|l|}{ Self-Awareness } \\
\hline My feelings affects my performance & 250 & 3.9960 & .91176 \\
\hline My skills and potentiality & 250 & 4.4040 & .49168 \\
\hline Know the formal and informal rules & 250 & 4.6400 & .76992 \\
\hline Know how to use my ability & 250 & 4.4760 & .66573 \\
\hline Take my own decision & 250 & 3.8640 & .74816 \\
\hline Conduct my job properly & 250 & 4.5200 & .60254 \\
\hline Know what organization want from me & 250 & 4.2120 & .72744 \\
\hline \multicolumn{4}{|l|}{ Self-Management } \\
\hline Manage my inner feelings & 250 & 4.1240 & .77914 \\
\hline Control myself in any situation & 250 & 4.3640 & .60744 \\
\hline Ensure transparency in my work & 250 & 4.1880 & .94882 \\
\hline Always try to improve myself & 250 & 4.3960 & .81599 \\
\hline Manage challenging task & 250 & 3.9000 & .68401 \\
\hline Working with honesty \& integrity & 250 & 4.4640 & .61499 \\
\hline \multicolumn{4}{|l|}{ Social Skill } \\
\hline Maintain positive relationship with faculties & 250 & 4.2480 & .70176 \\
\hline Curious to share information & 250 & 4.2880 & .84374 \\
\hline Try to solve inner conflict & 250 & 4.4320 & .80496 \\
\hline Seek mutual cooperation with my worker & 250 & 4.2800 & .72367 \\
\hline \multicolumn{4}{|l|}{ Self-Motivation } \\
\hline Capable to find my difficulties & 250 & 4.6400 & .76992 \\
\hline Know the issue that motivate me & 250 & 4.4760 & .66573 \\
\hline Try to remain optimist & 250 & 3.8640 & .74816 \\
\hline Monitor my success & 250 & 4.5200 & .60254 \\
\hline Listen my superior instruction attentively & 250 & 4.2120 & .72744 \\
\hline
\end{tabular}

Table 2 revels that the major 4 dimensions (Independent variable) affect emotional intelligence (dependent variable) in private university faculties in Bangladesh. Here in the above table, dimension highest rank and present a men score s 4.64 or more, which lies in the self-awareness that denotes more faculties are known about their organizations formal and informal rules correctly. On the other hand, a good SD is also found (.49\%) in the selfawareness dimension which presents that faculties are more aware about their own self-skill and potentialities. Employees are capable enough to find their difficulties, here mean score is $(4.64 \%)$. So this paper find out that faculties are more capable to find difficulties are considerably affected emotional intelligence. Most of the 
respondent try to solve their inner conflict by themselves, mean score is $(4.43 \%)$. Thus solving inner conflict with other faculties affected over Emotional Intelligence. Therefore, faculties from respected universities in their working place, work with honesty and integrity, mean score is $(4.46 \%)$. So honesty and integrity considerably affected emotional perception from private universities faculties.

\subsection{The Results of regression analysis}

Table-3 Predict the relationship confirm the model fitness

\begin{tabular}{|l|l|l|l|l|l|l|}
\hline \multicolumn{7}{|c|}{ Model Summary } \\
\hline Model & R & R Square & $\begin{array}{l}\text { Adjusted } \\
\text { Square }\end{array}$ & $\begin{array}{l}\text { Std. Error of the } \\
\text { Estimate }\end{array}$ & $\begin{array}{l}\text { Durbin- } \\
\text { Watson }\end{array}$ \\
\hline 1 & .333 & .111 & .096 & .70687 & 1.992 \\
\hline
\end{tabular}

\begin{tabular}{|l|l|l|l|l|l|}
\hline \multicolumn{7}{|c|}{ ANOVA $^{\mathbf{b}}$} & $\begin{array}{l}\text { Sum } \\
\text { Squares }\end{array}$ & df & $\begin{array}{l}\text { Mean } \\
\text { Square }\end{array}$ & F & Sig. \\
\hline Model & 15.219 & 4 & 3.805 & 7.614 & $.000^{\text {a }}$ \\
\hline Regression & 122.417 & 245 & .500 & & \\
\hline Residual & 137.636 & 249 & & & \\
\hline Total &
\end{tabular}

6.1.1 Predict the relationship between factors and emotional intelligence of faculties

Above table represents the value of correlation coefficient, $\mathrm{R}=0.333$ suggest that there is moderate positive correlation between emotional intelligence and self-awareness, self-motivation, self-management, social skills. However, only $1.11 \%$ (R-square values of .111) variation in emotional intelligence as self-awareness, selfmotivation, self-management, social skill and other factors.

Confirm the relationship model fitness- Above tables reveals that multiple analysis is preferred to examine the relationship between self-awareness, self-motivation, self-management, social skill factors with emotional intelligence on faculties. Four hypothesis are proposed and results are given in above table. The F-statics produced $(\mathrm{F}=7.614)$ is significant at 1 percent level (Sig. $\mathrm{F}<0.01)$ with 4 and 245 degree of freedom, consequently confirming the fitness for the model. The adjusted R2 is .096 , told that the four factors can correctly account for $09.6 \%$ variance in EI for faculty members.

Table-4 Factors affecting EI on Faculties

\begin{tabular}{|l|l|l|l|l|l|l|}
\hline \multicolumn{2}{|l|}{} & \multicolumn{2}{l|}{$\begin{array}{l}\text { Unstandardized } \\
\text { Coefficients }\end{array}$} & $\begin{array}{l}\text { Standardized } \\
\text { Coefficients }\end{array}$ & $\mathrm{t}$ & Sig. \\
\cline { 3 - 9 } Model & B & Std. Error & Beta & & \\
\hline \multirow{3}{*}{1} & Constant) & 5.894 & 1.200 & & 4.910 & .000 \\
\cline { 2 - 9 } & Self-Awareness & .932 & .256 & .307 & 3.636 & .000 \\
\cline { 2 - 9 } & Self-Management & .080 & .181 & .027 & .443 & .658 \\
\cline { 2 - 9 } & Social Skill & -.429 & .130 & -.199 & -3.294 & .001 \\
\cline { 2 - 9 } & Self-Motivation & -.985 & .223 & -.375 & -4.422 & .000 \\
\hline
\end{tabular}

\subsubsection{Factors affecting EI on Faculties (Table -4)}

The results of multiple regression for $\mathrm{H} 1$ as present in above table as present that self-awareness is a vital factor and significantly affect perception of EI on faculties $(\beta 1=0.307 ; \mathrm{t}$ value $=3.636 ; \mathrm{p}<0.05)$. Here, $\mathrm{H} 1$ is supported. So we can say that self-awareness have significant impact or influence upon. Self-Management is an important factor and significantly affect perception of EI on faculties, $(\beta 1=0.027$; value $=.443 ; p>0.05)$. Here, H2 is not supported. So self-management have negative impact on inter personal skills. Next, social skill is a vital factors, which negatively and notably affected emotional intelligence for faculties $(\beta=-.199$ : $\mathrm{t}$ value $=-3.294: \mathrm{p}<0.05)$. H3 is supported. So faculties can be able to increase managing relationship with others. Self-motivation is another essential factor and motivated the faculties. Here, $(\beta 1=0 .-375 ; \mathrm{t}$ value $=-4.422 ; \mathrm{p}<0.05)$ and significance level is zero. Here, H4 is also supported. So it can be said that Self-motivation helps to overcome difficulties.

\section{Limitations \& Further Research}

EI is a very emerging issue in the era of human behavior, as EI is directly or indirectly affected employees/faculties 
in the work place. To conduct this study, various limitations has been found and the further research can be-

- To find out the perception of faculties upon EI, 834 questionnaires has been send, but only 250 respondents are found.

- Unwillingness of respondents poses a great problem to complete this paper.

- Lack of understanding of questionnaire is another constraint.

- Further research study can be conducted upon the public and private institutions, banks, public universities, health organizations, NGOs, public or private school level that on how EI is impact on the behavior of employees on that workplace.

- Further research also can be conducted on-impact or relationship between the EI and Job satisfaction, employee morale, employee training, and employee performance and so on.

- Research can also be carried out sector wise to check emotional intelligence and its impact on others dimension.

\section{Conclusion}

In conclusion, this research highlights the perception level of faculties upon EI and how employees behave in their workplace. It also shows that the four dimensions (Self-awareness, Self-management, Social Skill and Selfmotivation) has direct or indirect influence on EI. The results of the present research study revealed out that there is a great impact or positive relationship exist between Emotional intelligence and self-awareness, self-motivation and social skill. This prove that faculties are known about their self-regulation meter, making own decision rationally, maintaining social relationship and knowing their own emotional make up (overcome the difficulties). On the other hand, this study also shows that faculties are less aware about their self-managing skill. Therefore, it is recommended that if training programs are imparting to improving emotional competencies as mostly selfmanagement skill then it would give better results in the workplace. As the world is changing and employees or faculties must be able to predict how to respond in different situations, changes, events and perfectly handle these reaction.

\section{References}

Ali, A. K. (2013). Employee Emotional Intelligence and Employee Performance in the Higher Education Institutions in Saudi Arabia: A Proposed Theoretical Framework. International Journal of Business and Social Science, 4 (9).

Ekmen. (1992). An Argument for basic Emotions. Cognition and Emotions , 6 (3/4), 169-200.

Fisher, \& Ashkanasy. (2000). The Emerging Role Emotions in Work life: An introduction. J. Org. Behavior , 21 (2), 123-129.

Georgiana, D. (2014, november 02). Emotionskills.com. Retrieved january 07, 2015, from http://www.emotionskills.com/four-dimensions-of-emotional-intelligence/

Mayer, J. D., \& Salovey, P. (1997). What is emotional intelligence? New York: Basic Books.

Peter, S., \& John, M. (n.d.). Daniel Goleman's five components of emotional intelligence. Retrieved january 07 , 2015, from http://www.sonoma.edu/users/s/swijtink/teaching/philosophy_101/paper1/goleman.htm

Salovery, P., \& Mayer, J. D. (1990). Emotionallintelligence. Baywood Publishing , 185-200.

Tahir, M., Saba, Q., \& Rabbia, A. (2013). Impact of Emotional Intelligence on the Performance of University Teachers. International Journal of Humanities and Social Science , 3 (18).

Goleman, D. 1995. Emotional intelligence. New York: Bantam.

Goleman, D. 1998. The Emotionally Intelligent Workplace: An EI-Based Theory of Performance (Chapter Three). Cherniss C. \& Goleman D. (Ed).Consortium for Research on Emotional Intelligence in Organizations.

Grayson, R. (n.d.). Emotional Intelligence: A Summary. Retrieved on 2013 from http://www.visionrealization.com

Schuetz, H. 2011. Acquiring social skills-the key to professional success. Retrieved July 21, 2013, from Magazine for International Management

Yeung R 2009, Emotional Intelligence, the New Rules Benin City, Beulah Land Publications.

Khokhar, C.P., and Kush, T. (2009). Emotional Intelligence and work performance among executives. Europe's Journal of Psychology, 1, 1-11.

Day, A. L., Carroll, S. A. 2004. Using an ability-based measure of emotional intelligence to predict individual performance, group performance, and group citizenship behaviors. Personality and Individual Differences, $36,1443-1458$.

George, J. M. 2000. Emotions and leadership: the role of emotional intelligence, Human Relations, 53: 1027-1055.

Gayathri,N \& Meenakshi,K 2013.A literature review of Emotional Intelligence: International Journal of Humanities and social Science Invention, Volumn 2 Issue 3 ,March 2013 (pp.42-51).

Ahmed, Zeeshan and Sabir Sarwat et al. November 2016.The impact of Emotional Intelligence on Employee's Performance in Public and Private Higher Educational Institutions of Pakistan: IOSR Journal of Business and Management (IOSR -JBM), Volume 18 Issue 11 ,November 2016 (pp.63-71). 


\section{Appendix A}

Questionnaire for the research on Perception of Emotional Intelligence (EI) of the Private University Faculty

Members of Bangladesh

Dear respondents,

We are going to conduct a research on -Perception of Emotional Intelligence of the Faculty Members of

Private Universities in Bangladesh. This questionnaire consist of statements that provide you with a opportunity to describe yourself by indicating the degree to which each statement is true of the way $u$ feel, think or act most of the time. There are five possible responses to each sentence make your choice on the answer sheet by putting $\operatorname{tick}(\sqrt{ })$ mark for each sentence. Your valuable, honest and unbiased decision is required for the research.

Institution

Designation

Age

Total experience

This is my $\left(n^{\text {th }}\right)$ job.

Income range

$$
\text { : }
$$

$\square$ Below $30000 \quad \square$ Below $40000 \quad \square$ Below $50000 \quad \square$ Above 60000

Marital Status

: $\square$ Married

$\square$ Single

$\square$ Others

\begin{tabular}{|c|l|l|l|l|l|l|}
\hline $\begin{array}{c}\text { S1 } \\
\text { no. }\end{array}$ & \multicolumn{1}{|c|}{ Personal traits } & $\begin{array}{c}\text { Strongly } \\
\text { agree }\end{array}$ & Agree & $\begin{array}{c}\text { Neither } \\
\text { agree nor } \\
\text { disagree }\end{array}$ & Disagree & $\begin{array}{c}\text { Strongly } \\
\text { disagree }\end{array}$ \\
\hline 1 & $\begin{array}{l}\text { I recognize my feelings which affect my } \\
\text { performance. }\end{array}$ & & & & \\
\hline 2 & I know my skill and potentiality. & & & & & \\
\hline 3 & I know the formal and informal rules. & & & & & \\
\hline 4 & $\begin{array}{l}\text { I know how to use my ability and } \\
\text { potentiality for my success. }\end{array}$ & & & & & \\
\hline 5 & I can take my own decision rationally. & & & & & \\
\hline 6 & I believe I can conduct my job properly. & & & & & \\
\hline 7 & $\begin{array}{l}\text { I try to find out what my organization } \\
\text { want from me }\end{array}$ & & & & & \\
\hline
\end{tabular}

B. Self-Management

\begin{tabular}{|c|l|l|l|l|l|l|}
\hline $\begin{array}{c}\text { Sl } \\
\text { no }\end{array}$ & \multicolumn{1}{|c|}{ Personal traits } & $\begin{array}{c}\text { Strongly } \\
\text { agree }\end{array}$ & Agree & $\begin{array}{c}\text { Neither } \\
\text { agree nor } \\
\text { disagree }\end{array}$ & Disagree & $\begin{array}{c}\text { Strongly } \\
\text { disagree }\end{array}$ \\
\hline 1 & $\begin{array}{l}\text { I can manage my inner feelings and } \\
\text { emotion well. }\end{array}$ & & & & & \\
\hline 2 & I can control myself in any situations. & & & & & \\
\hline 3 & I work with honesty and integrity. & & & & & \\
\hline 4 & $\begin{array}{l}\text { I ensure transparency and fairness in } \\
\text { delivering services. }\end{array}$ & & & & & \\
\hline $\mathbf{5}$ & $\begin{array}{l}\text { I am curious to learn in order to improve } \\
\text { my performances. }\end{array}$ & & & & & \\
\hline $\mathbf{6}$ & I can manage challenging goals and task. & & & & & \\
\hline
\end{tabular}

\section{Social Skill (Relationship Management)}

\begin{tabular}{|c|c|c|c|c|c|c|}
\hline $\begin{array}{l}\text { Sl } \\
\text { no. }\end{array}$ & Personal traits & $\begin{array}{c}\text { Strongly } \\
\text { agree }\end{array}$ & Agree & $\begin{array}{c}\text { Neither } \\
\text { agree nor } \\
\text { disagree }\end{array}$ & Disagree & $\begin{array}{l}\text { Strongly } \\
\text { disagree }\end{array}$ \\
\hline 1 & $\begin{array}{l}\text { I maintain a close relationship with my } \\
\text { supervisor and other faculty members. }\end{array}$ & & & & & \\
\hline 2 & $\begin{array}{l}\text { I am curious to share information and } \\
\text { resources. }\end{array}$ & & & & & \\
\hline 4 & I try to solve inter employee conflict. & & & & & \\
\hline 5 & $\begin{array}{l}\text { I listen to and seek mutual cooperation } \\
\text { from my co-worker. }\end{array}$ & & & & & \\
\hline
\end{tabular}


D. Self-Motivation

\begin{tabular}{|l|l|l|l|l|l|l|}
\hline $\begin{array}{l}\text { S1 } \\
\text { no. }\end{array}$ & \multicolumn{1}{|c|}{ Personal traits } & $\begin{array}{l}\text { Strongly } \\
\text { agree }\end{array}$ & Agree & $\begin{array}{l}\text { Neither } \\
\text { agree nor } \\
\text { disagree }\end{array}$ & Disagree & $\begin{array}{l}\text { Strongly } \\
\text { disagree }\end{array}$ \\
\hline 1 & $\begin{array}{l}\text { I can find the reason behind my stress, } \\
\text { anxious and difficulties. }\end{array}$ & & & & & \\
\hline 2 & I know the issues that motivate me. & & & & & \\
\hline 3 & I am optimist. & & & & & \\
\hline 4 & $\begin{array}{l}\text { I monitor my success after getting } \\
\text { motivation. }\end{array}$ & & & & & \\
\hline 5 & $\begin{array}{l}\text { I try to listen to my superior's } \\
\text { instruction attentively. }\end{array}$ & & & & & \\
\hline
\end{tabular}

\section{E. Emotional Intelligence}

\begin{tabular}{|l|l|l|l|l|l|l|}
\hline $\begin{array}{l}\text { S1 } \\
\text { no. }\end{array}$ & \multicolumn{1}{|c|}{ Personal traits } & $\begin{array}{l}\text { Strongly } \\
\text { agree }\end{array}$ & Agree & $\begin{array}{l}\text { Neither } \\
\text { agree nor } \\
\text { disagree }\end{array}$ & Disagree & $\begin{array}{l}\text { Strongly } \\
\text { disagree }\end{array}$ \\
\hline 1 & $\begin{array}{l}\text { I am highly fit to maintain the } \\
\text { psychological and cognitive issues. }\end{array}$ & & & & & \\
\hline
\end{tabular}

First Author Taslima Khatun is a senior Lecturer of HRM in Feni University, Bangladesh. After completing her BBA and MBA from Cumilla University she joined as a lecturer in 2014 in the Feni University. Along with this she has been working as an Assistant Coordinator (programs) as an additional responsibility of Feni University. Her research interest includes HRIS (Human Resource Information System), Women Entrepreneurship, Selection \& Training, Performance management and Emotional Intelligence.

Second Author Mahajabin Tabassum Sujana is a Lecturer of Marketing in Feni University, Bangladesh. After obtaining the BBA and MBA from Cumilla University, she joined the university in 2017 as a lecturer. She has the capability to do creative research. His research interest lies in Word of Mouth Marketing, Buzz Marketing, and Niche Marketing.

Third Author Mohammad Abul Khayer is an Assistant Professor of Marketing in Feni University, Bangladesh. After obtaining the MBA from Anglia Ruskin University, UK, he joined the university in 2013 as a Lecturer. Besides, he has been serving the university as the Student Adviser as an additional responsibility of the university. $\mathrm{He}$ is a disciple of creative work and research. His research interest includes services marketing, word of mouth marketing, niche marketing, entertainment marketing, academic integrity, wastes management etc. He has contributed as the Managing Editor and Assistant Editor of Feni University Journal Vol. 02 and Vol. 01 respectively. Before joining the Feni University, he served as the Duty Manager of Gamesmaster, a leisure software retailer in London, UK. Khayer esteems social responsibility highly; that is why, he has been involved in sociocultural activities for about 25 years. He has established and led a few socio-cultural organizations. 